\title{
Demographics as Moderator Between Perceived Easy of Use, Individual Awareness and Adoption of Mobile Financial Services
}

\author{
Wilberforce Witts ${ }^{1} \&$ Severine Kessy ${ }^{2}$ \\ ${ }^{1} \mathrm{PhD}$ student at University of Dar es Salaam Business School (UDBS), Tanzania \\ ${ }^{2}$ Senior Lecturer in the department of General Management at University of Dar es Salaam Business School \\ (UDBS), Tanzania \\ Correspondence: Wilberforce Witts, PhD student at University of Dar es Salaam Business School (UDBS), \\ Tanzania.E-mail: wwitts@yahoo.com
}

Received: August 25, 2021

doi:10.5539/ijbm.v16n12p53
Accepted: October 29, $2021 \quad$ Online Published: November 12, 2021

URL: https://doi.org/10.5539/ijbm.v16n12p53

\begin{abstract}
The number of mobile financial services users is keeping increasing in Tanzania. Despite such an increase, few individuals actively use mobile financial services. The adoption of these services may be contributed by either the different features of mobile financial services or demographics orientation. The current study used Unified Theory of Acceptance and Use of Technology and AMOS-SEM for data analysis. The findings revealed that the antecedents of mobile financial services, namely individual awareness and perceived ease of use significantly influence individual mobile financial services adoption. Demographics orientation was also found to have moderating effect on the relationship between individual awareness and perceived ease of use, and individual mobile financial services adoption. The paper makes a contribution in the theory used and contributes knowledge to the Tanzania national second financial inclusion policy 2018-2022 by considering demographics variables in analyzing different issues.
\end{abstract}

Keywords: demographics, mobile financial services adoption, financial inclusion

\section{Introduction}

Individual access to financial services is limited especially in developing countries. It is estimated that over 1.7 billion working-age adults worldwide, the majority of whom are residing in Sub-Saharan Africa, do not have access to formal financial services (World Bank, 2018). Simiyu and Oloko (2015) argue that access to financial services is a key factor to job creation, economic growth, financial stability, and poverty alleviation. Despite such importance, most individuals still face significant shortage in accessing financial services in Tanzania due to some fundamental barriers that limit the growth of financial inclusion. These barriers are supply side ones which include inappropriate services that do not meet demand side needs, high interest rates, and high costs of the service offered (URT, 2020). Other barriers are demand side ones such as information asymmetry, irregular income patterns and financial illiteracy.

Tanzanian being one of the poorest countries in the world (Mashimba \& Kühl, 2014), it needs well developed economic interventions to reduce poverty from the majority of its people. One of the suggested economic interventions suggested by scholars is to promote financial inclusion. The financial inclusion has recently gained recognition throughout the world as an essential economic and financial policy. Global policymakers and local financial institutions acknowledge the importance of financial inclusion as a foundation for economic development, financial sector stability, and poverty reduction (Abor, Amidu, \& Issahaku, 2018; Asongu \& Boateng, 2018; Kim, Zoo, Lee, \& Kang, 2018; URT, 2020).

In recognizing the importance of financial inclusion, the Government of Tanzania has taken several initiatives including establishing the National Microfinance Policy of 2000 and the First Financial Inclusion Framework 2014-2016. Despite such initiatives, many challenges persisted including continued focus of financial service providers in urban areas, increased informalities, and inadequate coordination as well as low use of other financial products and services. In addressing these shortcomings, the National Microfinance Policy 2000 and First Financial Inclusion Framework 2014-2016 were revised, which led to the development of the National Microfinance Policy 2017 and Second National Financial Inclusion Framework 2018-2022. 
The implementation of the financial inclusion framework led to an increase in access to formal financial services for adult population from $15.9 \%$ in 2009 to $65 \%$ in 2017 . The increase was mainly attributed to the introduction of mobile financial services. Mobile financial services have emerged as an essential catalyst of financial inclusion and contemporary innovation in providing financial services to the rural population (Lotto, 2018; Mariscal \& Rojas-Lozano, 2020; Ouma, Odongo, \& Were, 2017).

Mobile money technology has proven to be a significant transformation in accessing financial services by the unbanked communities because of its ease penetration (Gurme, 2019; Srivastava, 2015). The mobile money technology has facilitated the provision of financial services both in urban and rural areas and has precipitated the development of customized financial products and services due to its convenience and affordability (Osabuohien \& Karakara, 2018;Mazer \& Rowan, 2016) .

Despite the initiatives done by Tanzanian government, individual adoption of mobile financial services is still low in Tanzania (TCRA, 2020). The TCRA's (2020) report says that out of 83 million registered mobile phone subscribers, only 23 million subscribers actively use mobile financial services; hence, 60 million registered subscribers predominantly found in the rural areas do not use mobile financial services (URT, 2020). This situation raises a doubt on mobile financial services' contribution to the growth of the economy, financial sector stability and poverty eradication. Research has found that there are several challenges emanating from mobile financial services that influence individuals to adopt mobile financial services. These challenges include money security, customer dissatisfaction, decrease revenue, decrease sales revenue, and profit decrease. Other scholars such as Ahmad and Ghani (2010) and Akyoo and Sife (2015) mention other factors that influence the adoption of mobile financial services such as price value, perceived risk, hedonic motivation, market structure, pricing and regulatory implications.

Even though several challenges facing individual adoption of mobile financial services have been mentioned, other mobile networks perform well in this area of individual adoption of mobile financial services. There are several factors that, if taken into consideration, might result in the increase of money transfer, electronic payment of goods and services and saving and receiving of credits. These factors included having sufficient knowledge on individual awareness, perceived cost, perceived ease of use, and perceived usefulness when moderated by the demographics effect, as well as designing services which are appropriate for meeting demand and supply needs.

Mobile financial services were introduced in 2007 in Tanzania whereby M-pesa was the first to be introduced followed by Tigo Pesa, EzyPesa and Airtel Money. During the introduction stage, mobile money services in Tanzania were used for just transferring of money only. This means that individuals used mobile money services only for sending money to their friends, relatives and family members. Later on the services expanded to include savings, electronic payment of goods and services, buying airtime credits and paying bills.

Despite such development of mobile financial services in Tanzania, Ouma et al. (2017) contend that new technologies facilitate some capabilities and limit others, thereby bringing diverse development outcomes. Other factors like social, economic, knowledge and status of an individual contribute on to development of new technologies and their outcomes. Mobile network operators should consider these demographics features in designing their products and services. Such consideration will enable individuals to adopt the mobile technology and benefit fully from their mobile financial services. This may imply that mobile financial services may not have significant contribution on savings, buying of airtime credits, electronic payment, money transfer and bill payments if the mobile network operators do not consider demographics traits when designing their products and services. In addition, the demographics orientation may also have a moderating effect on the relationship between features of mobile financial services and the adoption.

A study concerning adoption of mobile financial services by Akyoo and Sife (2015) did not include the influence of demographics orientation on mobile financial services adoption. However, a study by Chong (2013) revealed that demographics orientation plays a significant role in improving adoption of mobile financial services. It is expected that mobile network operators who consider demographics traits of individuals in designing their products and services will perform better than those who do not consider demographics traits when designing their products and services.

In this case, it is likely that an increase in savings, receiving credits, electronic payment of goods and services, money transfer and bill payment may be influenced by the demographics orientation. This is justified by studies like that of Shareef, Baabdullah, Dutta, Kumar, and Dwivedi (2018) whose one of the findings was that adoption of mobile financial services is multidimensional; hence, it cannot be influenced by a single factor.

Demographics variables include level of income, qualification, age, gender, experience, occupation, and marital status. The current study focuses on four forms of demographics variables, namely level of income, level of 
education, age and gender since they are mostly proven by other researchers to be important factors in the adoption of mobile financial services. This may imply that factors such as awareness, perceived performance, perceived ease of use may not have significant contribution on adoption of mobile financial services without being moderated by demographics variables. However, most scholars mainly focus on the direct relationship between mobile financial services and adoption and not on the moderation of demographics variables on the adoption. Considering the identified limitations of existing studies and wider influence of demographics on mobile financial services, it was considered important to investigate the influence of demographics on adoption of mobile financial service in rural Tanzania.

\section{Review of Literature}

The current study uses demographics factors as moderating variable and a guiding theory of Unified Theory of Acceptance and Use of Technology (UTAUT). The UTAUT aims to explain user intentions to use information and communications technology and subsequent usage behavior. The theory holds that four key constructs, namely performance expectancy, effort expectancy, social influence, and facilitating conditions are direct determinants of use intention and behavior. On the other hand, demographics such as gender, age, experience, and voluntariness of use are posited to moderate the impact of critical constructs on usage intention and behavior (Abdinoor \& Mbamba, 2017; Lee et al., 2012; Venkatesh, Morris, Davis, \& Davis, 2003). The quantitative research design was used to help understand and explain factors influencing mobile financial services adoption in rural Tanzania.

Mobile financial service encompasses a chain of financial products and services rendered using mobile devices, such as cellular phones or personal digital assistants (Adjei, Odei-Appiah, \& Tobbin, 2019). Mobile financial services, also referred to as mobile money, includes a wide range of financial products and services accessible to consumers through mobile phone devices (David-West, Iheanachor \& Umukoro, 2019). Mobile money is an economic innovation that has played a pivotal role in financial inclusion at the bottom of the pyramid. According to David-West, Iheanachor and Umukoro (2019), mobile money rides on information technology and alternative banking channels to provide access to the mobile financial services to customers who cannot afford the cost of formal financial services through conventional bank-led channels (Odoom \& Kosiba, 2020).

The adoption of mobile financial services is not the same for all countries across the globe; consequently, the adoption of mobile financial services in developed countries is higher compared to developing countries, and the rate of adoption in urban areas is higher than in rural areas (Marumbwa \& Mutsikiwa, 2013). In the current study, mobile financial services adoption is referred to as a customer's willingness to use mobile financial services. Adoption largely hinges on customer's awareness of different mobile financial products and services offered by Mobile Network Operators (MNOs) as well as perceived ease of use, perceived usefulness, perceived cost, and demographics variables.

Davis (1989) defines perceived ease of use as the degree to which a person believes that using a particular system would be free from effort. The degree of mobile financial services adoption hinges on individual user values such as attitudes, social needs, perceptions of ability psychologically, and technologically (Shareef et al., 2018). Perceived ease of use of mobile financial services is user-friendly processes and easy to follow steps by both technology elite and non-elite segments of the society.

Moreover, awareness or knowledge of the availability of various mobile financial products and services is likely to influence the rate of adoption and usage (Shareef et al., 2018). Bhanot, Bapat and Bera (2012) argue that individual awareness of financial services is the availability of information on access and adoption to financial services. Awareness of mobile financial services positively impacts perceived usefulness and individual awareness of use of mobile financial services ( Kim et al., 2018; Lwoga \& Lwoga, 2017). In the current study, individual awareness of mobile financial services is construed as a situation where rural-based households have adoption of the mobile financial services.

\subsection{Empirical Literature Review}

Economides and Jeziorski (2016) assessed the impact of mobile money services in alleviating financial exclusion in developing countries with a specific focus on Tanzania. The study was centered in Dar es Salaam using a sample of 210 respondents. The study used a causal relationship approach with three variables identified for testing, including money transfer, short-distance money, self-transportation, and money storage for short to medium periods. The study employed multiple linear regression in establishing the relationship among study variables on the dependent people. The findings revealed that there had been a willingness to use the financial services to avoid walking with cash among many people. The business has experienced a positive effect of the suggested variables for testing since they demonstrated positivity and significant outcomes. 
Abdinoor and Mbamba (2017) conducted a study to assess factors influencing consumers' adoption of mobile financial services in Tanzania using the technology acceptance model (TAM). The study was carried in Kinondoni district in Dar es Salaam city through explanatory design with four variables, namely individual awareness, perceived usefulness, perceived benefits, and cost-effectiveness. A sample of 200 respondents was used to generate findings from both users and non-users of mobile financial services. Regression analysis was used to determine the existing relationship among consumer adoptions of mobile financial services. The findings indicated that all four variables identified for testing are positive, with a significant effect on adopting mobile financial services for financial inclusion.

Al-rawahna, Hung, and Chen (2018) conducted a study on factors responsible for promoting customers' adoption, intentions, and perceived risk of using e-banking services in Jordan. The researchers used quantitative research design and extended the Unified Theory of Acceptance and use Technology (UTAUT) to examine the appropriate conceptual model. Survey questionnaires and convenience sampling technique were used in data collection, and Structural Equation Modeling (SEM) was used in data analysis. The findings indicated that performance expectancy, price value, effort expectancy, perceived risk, and hedonic motivation significantly influence customers' behavior towards adopting e-banking services.

Richard and Mandari (2017) conducted a study in Ilala district in Dar es Salaam to establish factors that promote mobile banking services. The study used the quantitative research method, the Technology Acceptance Model (TAM), and Transaction theory. A structured questionnaire was used to collect data from a sample size of 120 respondents who were using mobile phones. The researchers used multiple regression and pearson correlation in data analysis and found that two factors, namely ease of use and customer awareness have a considerable positive influence on promoting mobile banking services. On the other hand, it was established that perceived risk and transaction costs have negative influence on adopting mobile financial services.

Akhtar, Irfan, Sarwar, and Rashid (2019) sought to establish factors influencing individual intention to adopt mobile banking in China and Pakistan. The study was conducted using a quantitative research method and the Technology Acceptance Model (TAM). Online and offline questionnaires were employed to collect data from 278 Pakistan and 311 Chinese respondents respectively, with 19 questionnaires not completed. The data analysis was performed using multiple regression IBM SPSS Software. It was observed that perceived usefulness, social influence, and perceived ease of use are significant predictors of individual intention to adopt m-banking in Pakistan. In contrast, perceived usefulness is an essential predictor in China. Cultural values were observed as a dampening factor in a positive relationship between social influence and individual intentions.

Chawla and Joshi (2017) linking elderly respondents found that older people are averse to adopting newer technologies. They moreover found that age has a moderating effect on older people's intention to play video games and that gender moderates the relationship between perceived ease of use, perceived enjoyment and intention to use information technology. Chawla and Joshi ( 2017) furthermore found that users with low education level will perceive high barriers to internet and electronic commerce access as compared to users with high education level. A higher level of education may possibly give rise to a greater level of understanding in new technologies, thereby accelerating the early adoption of new technology.

\section{Methodology}

\subsection{Research Model and Hypothesis of the Study}

The following are the hypothesis tested in this research paper.

$\mathrm{H}_{1}$ : Perceived ease of use has a positive influence on individual mobile financial services adoption in rural Tanzania.

$\mathrm{H}_{2}$ : Individual awareness has a positive influence on individual mobile financial services adoption in rural Tanzania.

$\mathrm{H}_{5} \mathrm{~A}$ : Age has a moderating effect on the influence of perceived ease of use and of individual awareness on individual mobile financial services adoption in rural Tanzania.

$\mathrm{H}_{5 \mathrm{~B}}$ : Level of income has a moderating effect on the influence of perceived ease of use and of individual awareness on individual mobile financial services adoption in rural Tanzania.

$\mathrm{H}_{5 \mathrm{C}}$ : Gender has a moderating effect on the influence of perceived ease of use and of individual awareness on individual mobile financial services adoption in rural Tanzania.

H5C: Level of education has a moderating effect on the influence of perceived ease of use and of individual awareness on individual mobile financial services adoption in rural Tanzania. 


\subsection{Research Instrument and Development}

This instruments used in the current study were aimed at collecting quantitative data. A questionnaire was used to collect the data and it was categorized into three sections, namely A, B and C. Section A focused on the demographic characteristics of the respondents. Section B explained different perceptions by different users and non-users of mobile financial services. Section $\mathrm{C}$ included the individual mobile financial services adoption; items were divided into five major groups, namely credits, deposits, money transfers, electronics payments of the services and goods and bill payments.

\subsection{Research Design and the Sample}

The current study was conducted among users and non-users of the mobile financial services in Mtwara region (Nanyumbu, Masasi, Nachingwea, and Tandahimba districts), in Tanzania. Cross sectional research design was utilized in the current study. Simple random sampling method was applied to get the sample of 380 respondents for the study. The data were collected from both users and non-users of the mobile financial services in different areas in rural Mtwara. Copies of a structured questionnaire was distributed to the users and non-users for the data collection to fill in.

Table 1 contains the characteristics of the respondents for the study. As the table indicates, majority of the respondents $(56.6 \%)$ were male and (43.4) were female. Also, majority of the respondents $(35.8 \%)$ were aged between 20 and 25 years, followed by $27.9 \%$ who were aged between 26 and 30, the third age group was $12.9 \%$ aged between 31 and 35, and the fourth group (10\%) was aged between 36 and 40 . Moreover, as indicated in Table 1, majority of the respondents (44.5\%) received less than Tanzanian Shillings (TZS) 50,000 monthly and majority of the respondents $(44.5 \%)$ had completed secondary school education.

Table 1. Demographic details of the respondents

\begin{tabular}{|c|c|c|c|c|}
\hline No. & Detail & Category & Frequency & Percent \\
\hline \multirow{3}{*}{1.} & \multirow{3}{*}{ Gender } & Male & 215 & 56.6 \\
\hline & & Female & 165 & 43.4 \\
\hline & & Total & 380 & 100 \\
\hline \multirow{10}{*}{2.} & \multirow{10}{*}{ Age } & $20-25$ & 136 & 35.8 \\
\hline & & 26 to 30 & 106 & 27.9 \\
\hline & & 31 to 35 & 49 & 12.9 \\
\hline & & 36 to 40 & 38 & 10.0 \\
\hline & & 41 to 45 & 15 & 3.9 \\
\hline & & 46 to 50 & 15 & 3.9 \\
\hline & & 51 to 55 & 8 & 2.1 \\
\hline & & 56 to 60 & 6 & 1.6 \\
\hline & & 61 to 65 & 7 & 1.8 \\
\hline & & Total & 380 & 100 \\
\hline \multirow{6}{*}{3.} & \multirow{6}{*}{ Monthly Income } & Less than TZS 50,000 & 169 & 44.5 \\
\hline & & Above TZS 50,000 to 100,000 & 116 & 30.5 \\
\hline & & Above TZS 100,000 to 200,000 & 49 & 12.9 \\
\hline & & Above TZS 200,000 to 500,000 & 26 & 6.8 \\
\hline & & Above TZS 500,000 & 20 & 5.3 \\
\hline & & Total & 380 & 100 \\
\hline \multirow{5}{*}{4.} & \multirow{5}{*}{ Education Level } & Informal Education & 27 & 7.1 \\
\hline & & Primary Education & 78 & 20.5 \\
\hline & & Secondary Education & 169 & 44.5 \\
\hline & & University/College & 106 & 27.9 \\
\hline & & Total & 380 & 100 \\
\hline
\end{tabular}

Source: Survey data (2020).

\section{Analysis and Results}

\subsection{Descriptive Analysis}

The mean scores were used to describe and rank the key variables of the current study. The study applied the 
categories of mean results as proposed by Oxford (1990) and Oxford and Burry-Stock (1995). The mean results were categorized into three groups, i.e. low (mean score from 0.1 to 2.4), medium (mean score from 2.5 to 3.4) and high (mean score from 3.5 to 5). The standard deviation was used to measure the amount of variation or dispersion of a set of values. A low standard deviation indicates that the values tend to be close to the mean of the set, while a high standard deviation indicates that the values are spread out over a wider range. Refer Table 2.

Table 2. Descriptive Statistics

\begin{tabular}{|c|c|c|c|c|c|}
\hline Variables and items & $\begin{array}{l}\mathrm{N} \\
\text { Statistic }\end{array}$ & $\begin{array}{l}\text { Mean } \\
\text { Statistic }\end{array}$ & Std. Error & $\begin{array}{l}\text { Std. Deviation } \\
\text { Statistic }\end{array}$ & $\begin{array}{l}\text { Variance } \\
\text { Statistic }\end{array}$ \\
\hline \multicolumn{6}{|l|}{ Perceived Ease of Use } \\
\hline Easy to learn about financial services & 380 & 3.9711 & .04615 & .89955 & .809 \\
\hline Simple mobile financial services procedures & 380 & 3.8947 & .04970 & .96890 & .939 \\
\hline Easy to fulfill banking needs via mobile & 380 & 3.4737 & .05644 & 1.10018 & 1.210 \\
\hline Much time to learn mobile financial services & 380 & 3.2737 & .06018 & 1.17307 & 1.376 \\
\hline $\begin{array}{l}\text { Many challenges in using mobile financial } \\
\text { services }\end{array}$ & 380 & 3.5500 & .05785 & 1.12779 & 1.272 \\
\hline $\begin{array}{l}\text { Easy to access credit, to send money and do } \\
\text { payments }\end{array}$ & 380 & 3.5500 & .05578 & 1.08729 & 1.182 \\
\hline \multicolumn{6}{|l|}{ Individual Awareness } \\
\hline Awareness of mobile financial services offered & 380 & 3.9053 & .05031 & .98080 & .962 \\
\hline $\begin{array}{l}\text { Mobile network operators informs financial } \\
\text { services offered }\end{array}$ & 380 & 4.0053 & .14385 & 2.80406 & 7.863 \\
\hline Borrow money easil via mobile financial services & 380 & 3.2289 & .07260 & 1.41522 & 2.003 \\
\hline $\begin{array}{l}\text { Mobile network operators informed on financial } \\
\text { services offered }\end{array}$ & 380 & 3.9368 & .05352 & 1.04324 & 1.088 \\
\hline Possible sending and receiving money & 380 & 4.1395 & .05254 & 1.02425 & 1.049 \\
\hline Save and borrow money & 380 & 3.6737 & .05936 & 1.15722 & 1.339 \\
\hline \multicolumn{6}{|l|}{ Adoption of Mobile Financial Services } \\
\hline $\begin{array}{l}\text { Receiving credit via mobile network operators } \\
\text { easily }\end{array}$ & 380 & 3.8921 & .05692 & 1.10954 & 1.231 \\
\hline Easy to transfer money & 380 & 4.2658 & .04066 & .79270 & .628 \\
\hline Possible to pay bills easily & 380 & 4.2211 & .04498 & .87690 & .769 \\
\hline Save money easily & 380 & 4.1158 & .04661 & .90863 & .826 \\
\hline Purchases of goods and payments easily & 380 & 3.9368 & .05429 & 1.05831 & 1.120 \\
\hline $\begin{array}{l}\text { Mobile financial services connected to banks } \\
\text { easily }\end{array}$ & 380 & 4.0079 & .05157 & 1.00523 & 1.010 \\
\hline
\end{tabular}

Source: SPSS Output.

Table 2 shows the descriptive analysis of the variables and items. The discussion is based on the mean of the items used in the variables

\subsection{Perceived Ease of Use}

Mean results indicated that perceived ease of use is highly considered as a factor for adoption. The mean scores of the perceived ease of use ranged from 3.2 to 3.9 which indicated the high perception on the ease of use of the mobile financial services. Specifically, easy to learn about financial services was considered highly with the mean score of 3.971, followed by simple mobile financial services procedures with the mean score of 3.894, easy to fulfill banking needs via mobile with the mean score of 3.473, much time to learn mobile financial services with the mean score of 3.273, many challenges in using mobile financial services with the mean score of 3.550 and easy to access credit, sending money and payments with the mean score of 3.550. The mean results hence showed that easy to learn about the use of mobile financial services is highly perceived under the perceived ease of use of mobile financial services.

\subsection{Individual Awareness}

The mean scores on the individual awareness practices on the adoption of the mobile financial services were as follows: awareness of mobile financial services offered with the mean score of 3.905, mobile network operators 
informs people about mobile financial services offered with the mean score of 4.005 , borrow money easily via mobile financial services with the mean score of 3.228, payment of bills via mobile financial services with the mean score of 3.936, possible sending and receiving money with the mean score of 4.139 and save and borrow money with the mean score of 3.673. Thus, it is clear that mobile network operators inform people about mobile financial services offered because it has the highest mean score of 4.005 .

\subsection{Individual Mobile Financial Adoption}

Regarding the adoption of the mobile financial services practices, Table 2 indicates the items and their mean scores as follows: receiving credit via mobile network operators easily with the mean score of 3.892 , easy to transfer money with the mean score of 4.265 , possible to pay bills easily with the mean score of 4.221 , save money easily with the mean score of 4.115 , purchases of goods and payments easily with the mean score of 3.936 and Mobile financial services connected to bankseasily with the mean score of 4.007 . The easy to transfer money has the highest mean score of 4.265 .

\subsection{Reliability Estimates}

Reliability refers to the degree to which the scale produces consistent results if repeated measures are made. Cronbach's alpha enables measurement of the reliability of different variables. It provides estimates of how much variation in scores of different variables is due to random errors or chance. Refer Table 3.

Table 3. Reliability statistics of constructs

\begin{tabular}{llll}
\hline Practices & No. of Items & $\begin{array}{l}\text { Cronbach's } \\
\text { Coefficient }\end{array}$ & Alpha \\
\hline Perceived Ease of Use & 6 & 0.746 \\
Perceived Cost & 6 & 0.800 \\
Individual Awareness & 6 & 0.796 \\
Perceived Usefulness & 6 & 0.723 \\
Individual Mobile Financial Services Adoption & 6 & 0.914 \\
\hline
\end{tabular}

Source: Field Data (2021).

\subsection{Validity and Reliability}

To test the reliability and validity of constructs, confirmatory factor analysis model was estimated using Analysis of Moments Structures (AMOS) version 26, and path analysis was used to measure the association of independent variable with dependent variable. In total, 380 copies of the questionnaire were coded into SPSS for data screening, data cleaning and spotting multivariate outliers. Refer Table 4.

Table 4. Confirmatory factor analysis

\begin{tabular}{llllll}
\hline Variables & Label & $\begin{array}{l}\text { Standardized } \\
\text { Factor Loading }\end{array}$ & $\mathrm{R}^{2}$ & $\begin{array}{l}\text { Composite } \\
\text { Reliability }\end{array}$ & AVE \\
\hline IA & IA2 & 0.86 & 0.88 & & \\
& IA4 & 0.76 & 0.65 & 0.757 & 0.807 \\
& IA5 & 0.71 & 0.77 & & \\
& IA6 & 1.00 & 0.92 & & 0.884 \\
\hline PE & PE1 & 0.74 & 0.79 & 0.790 & \\
\hline \multirow{5}{*}{ F61 } & & & & & \\
& PE3 & 0.80 & 0.56 & & \\
& PE4 & 0.78 & 0.63 & & \\
& PE5 & 0.90 & 0.59 & & \\
& PE6 & 1.00 & 0.85 & & \\
& F1 & 1.00 & 0.81 & & \\
& F3 & 0.70 & 0.60 & & \\
& F4 & 0.88 & 0.76 & 0.767 & \\
& F5 & 1.04 & 0.91 & & \\
& F6 & 0.98 & 0.83 & & \\
\hline
\end{tabular}




\subsection{Data Analysis and the Results}

In order to verify the factors of the three variables, the fitness of model was defined as confirmatory factory analysis (CFA; Ho, 2006) and the model fit was found to have adequate data. Table 4 represents the results of CFA for all the three variables in form of validity of scale and goodness of fit. All the indicators of AMOS output confirm that all the variables have good results regarding goodness of fit and no modifications was required. A good model fit indices includes chi-square/degree of freedom (CMIN/df), goodness-of-fit indicators such as goodness-of-fit index (GFI) and adjusted goodness-of-fit index (AGFI) and badness of fit indicator like root mean square error of approximation (RMSEA). The results show that all the indicators of model fit are within the permitted rates and is consistent with past studies (Bentler \& Bonett, 1980; Hooper, Coughlan, \& Mullen, 2008; Steiger, 2007).

\subsection{Model Fit}

The past studies show that there are positive relationships between individual awareness, perceived variables is accomplished in AMOS graphics, as it is presented in Table 5 (model fit). The values of GFI, Tucker-Lewis index (TLI), comparative fit index (CFI) and incremental fit index (IFI) fulfil the conditions of model fit, as they are more than 0.90 . The values of CMIN/df less than the recommended value [36][37] in the model, represent a better fit of the data.

Table 5. Measurement of model of different constructs

\begin{tabular}{lllllll}
\hline Variables & AGFI & CFI & RMSEA & CMIN/df & NFI & IFI \\
\hline IA & 0.80 & 0.92 & 0.08 & 4.43 & 0.899 & 0.92 \\
PU & 0.92 & 0.95 & 0.03 & 3.90 & 0.800 & 0.87 \\
F61 & 0.90 & 0.88 & 0.07 & 2.11 & 0.711 & 0.22 \\
\hline
\end{tabular}

Source: SPSS Amos output.

\subsection{Path Analysis Results}

Path analysis was done to test the developed hypothesis. The result of path analysis has been shown in Table 6 . The table indicates the regression weight and critical ratio test that signifies individual awareness $(* * *, p<0.05)$ and perceived ease of use $(* * *, p<0.05)$ have a strong association with mobile financial services adoption. Thus, the findings of this study support $\mathrm{H} 1$ and $\mathrm{H} 2$. Thus, hypothesis $\mathrm{H} 1$ and $\mathrm{H} 2$ are accepted.

Table 6. Result of structural model

\begin{tabular}{lllll}
\hline Paths & Estimates & S.E & C.R & P \\
\hline PE F11 & 2.299 & 5.335 & .431 & .007 \\
PC F11 & -.277 & .553 & -.500 & .010 \\
IA F11 & 1.211 & 4.248 & -.285 &.$* * *$ \\
PU F11 & 1.444 & 1.776 & .813 & .003 \\
\hline
\end{tabular}

Source: SPSS Amos output.

\subsection{Moderating Analysis of the Variables}

For respondents aged between 20 and 25 years, perceived ease of use and individual awareness showed moderating effect on the mobile financial services adoption of the respondents. This also shows a stronger relationship of adoption of mobile financial services compared to other age groups.

For respondents aged between 26 and 30, perceived ease of use shows moderating effect on mobile financial services adoption while the factor, individual awareness was not significant for those aged group respondents. This also shows a stronger relationship of adoption of mobile financial services by this age group.

The age group between 31 and 35 has a significant influence on mobile financial services adoption, and has a significance on the perceived ease of use and on individual awareness.

The group between 36 and 40 adopts mobile financial services highly too. The results of the coefficient values of the independent variables show that perceived ease of use and individual awareness were significant for this age 
group of respondents.

Mobile financial services adoption is also high at this age group of 41 to 45 years. The results of the coefficient values of the independent variables show that perceived ease of use, and individual awareness were significant for this age group of respondents.

As regards the age group of between 46 and 50, the adoption of the mobile financial services is also high at this age group. The results of the coefficient values of the independent variables show that perceived ease of use and individual awareness were significant for this aged group respondents.

The findings show that there is less mobile financial services adoption for the age group of between 51 and 55 . The results of the coefficient values of the independent variables indicate that perceived ease of use was significant while individual awareness was not significant for this age group of respondents.

In the age between 56 and 60 , the findings show that there is less adoption of the mobile financial services. The results of the coefficient values of the independent variables indicate that perceived ease of use and individual awareness were significant for this age group of respondents.

Therefore, from the above analysis it can be concluded that, the young age group is highly engaged in mobile financial services adoption. The factors perceived ease of use, and individual awareness favor the younger age than the older age.

Table 7. Effects of Age on Mobile Financial Services Adoption

\section{Model Summary}

\begin{tabular}{llllll}
\hline $\begin{array}{l}\text { Income } \\
\text { level }\end{array}$ & $\mathbf{R}$ & $\mathbf{R 2}$ & Adjusted $\mathbf{R}^{2}$ & Std. Error estimate & Durbin-Wtson \\
\hline $20-25$ & $0.866^{\mathrm{a}}$ & 0.901 & 0.700 & 0.502 & 1.783 \\
$26-30$ & $0.735^{\mathrm{b}}$ & 0.828 & 0.898 & 0.731 & 2.322 \\
$31-35$ & $0.876^{\mathrm{c}}$ & 0.342 & 0.103 & 0.342 & 1.231 \\
$36-40$ & $0.788^{\mathrm{b}}$ & 0.331 & 0.543 & 0.231 & 2.565 \\
$41-45$ & $0.987^{\mathrm{a}}$ & 0.753 & 0.721 & 0.453 & 1.675 \\
$46-50$ & $0.678^{\mathrm{c}}$ & 0.264 & 0.432 & 0.277 & 1.564 \\
$51-55$ & $0.775^{\mathrm{b}}$ & 0.933 & 0.554 & 0.456 & 1.241 \\
$56-60$ & $0.578^{\mathrm{d}}$ & 0.732 & 0.645 & 0.675 & 1.442 \\
$61-65$ & $0.464^{\mathrm{c}}$ & 0.355 & 0.749 & 0.321 & 2.337 \\
$66-70$ & $0.543^{\mathrm{d}}$ & 0.324 & 0.022 & 0.568 & 2.990 \\
\hline
\end{tabular}

Table 8. Anova Results Age

\begin{tabular}{lllllll}
\hline I & & Sum of squares & Df & Mean square & F & Sig. \\
\hline \multirow{2}{*}{$20-25$} & Regression & 50.201 & 4 & 37.550 & 113.641 & $0.000^{\mathrm{a}}$ \\
& Residual & 2.712 & 99 & 0.330 & & \\
& Total & 182.913 & 103 & & & \\
& Regression & 46.348 & 4 & 36.562 & 138.000 & $0.000^{\mathrm{b}}$ \\
$26-30$ & Residual & 20.785 & 86 & 0.265 & & \\
& Total & 170.033 & 90 & & & \\
& Regression & 50.796 & 5 & 21.454 & 24.445 & $0.004^{\mathrm{d}}$ \\
\multirow{3}{*}{$31-35$} & Residual & 13.913 & 58 & 0.343 & & \\
& Total & 80.710 & 75 & & & \\
& Regression & 23.334 & 9 & 0.554 & 2.987 & $0.001^{\mathrm{b}}$ \\
$36-40$ & Residual & 9.432 & 21 & 0.132 & & \\
& Total & 32.342 & 56 & & & \\
& Regression & 43.212 & 23 & 23.243 & 67.776 & $0.000^{\mathrm{d}}$ \\
$41-45$ & Residual & 33.987 & 34 & 0.232 & & \\
& Total & 8.432 & 88 & & & \\
& Regression & 21.221 & 17 & 12.698 & 45.575 & $0.051^{\mathrm{c}}$ \\
\multirow{2}{*}{$46-50$} & Residual & 8.422 & 44 & 0.764 & & \\
& Total & 67.225 & 75 & & & \\
\hline
\end{tabular}




\begin{tabular}{lllllll}
\hline \multirow{5}{*}{$51-55$} & Regression & 45.332 & 11 & 39.917 & 91.988 & $0.072^{\mathrm{b}}$ \\
& Residual & 34.532 & 23 & 0.432 & & \\
& Total & 34.657 & 85 & & & \\
& Regression & 41.567 & 4 & 37.226 & 55.899 & $0.090^{\mathrm{c}}$ \\
$56-60$ & Residual & 5.554 & 45 & 0.569 & & \\
& Total & 66.644 & 67 & & & \\
& Regression & 34.543 & 5 & 34.596 & 157.776 & $0.123^{\mathrm{d}}$ \\
$61-65$ & Residual & 2.988 & 51 & 0.323 & & \\
& Total & 43.221 & 60 & & & \\
& Regression & 43.123 & 6 & 0.618 & 67.990 & $0.137^{\mathrm{c}}$ \\
$66-70$ & Residual & 6.334 & 34 & 0.334 & & \\
& Total & 34.332 & 66 & & & \\
\hline
\end{tabular}

Table 9. Results of the coefficients value for age

\begin{tabular}{|c|c|c|c|c|c|c|}
\hline Age & & B & Std. Error & Standardized coefficients & $\mathbf{T}$ & Sig. \\
\hline \multirow{3}{*}{$20-25$} & (constant) & 0.941 & 0.743 & & 0.005 & 0.003 \\
\hline & Perceived_Ease & 0.042 & 0.489 & 0.032 & 0.539 & 0.634 \\
\hline & Individual_awareness & 0.457 & 0.274 & 0.543 & 3.231 & 0.001 \\
\hline \multirow{3}{*}{$26-30$} & (constant) & 1.541 & 0.325 & & 5.332 & 0.000 \\
\hline & Perceived_Ease & 0.345 & 0.148 & 0.432 & 3.875 & 0.000 \\
\hline & Individual_awareness & 0.127 & 0.129 & 0.143 & 1.198 & 0.234 \\
\hline \multirow{3}{*}{$31-35$} & (constant) & 0.118 & 0.867 & & 4.923 & 0.000 \\
\hline & Perceived_Ease & 0.886 & 0.174 & 0.443 & 0.271 & 0.029 \\
\hline & Individual_awareness & 0.431 & 0.107 & 0.345 & 1.275 & 0.020 \\
\hline \multirow{3}{*}{$36-40$} & (constant) & 1.876 & 0.165 & & -0.007 & 0.016 \\
\hline & Perceived_Ease & 0.167 & 0.132 & 0.556 & 0.293 & 0.031 \\
\hline & Individual_awareness & 0.221 & 0.069 & 0.119 & 0.045 & 0.021 \\
\hline \multirow{3}{*}{$41-45$} & (constant) & 0.632 & 0.443 & & -0.321 & 0.082 \\
\hline & Perceived_Ease & 0.443 & 0.267 & 0.221 & 0.864 & 0.000 \\
\hline & Individual_awareness & 0.236 & 0.220 & 0.117 & 0.221 & 0.000 \\
\hline \multirow{3}{*}{$46-50$} & (constant) & 0.114 & 0.010 & & 3.221 & 0.022 \\
\hline & Perceived_Ease & 0.223 & 0.221 & 0.224 & 1.332 & 0.020 \\
\hline & Individual_awareness & 0.775 & 0.126 & 0.321 & 0.764 & 0.178 \\
\hline \multirow{3}{*}{$51-55$} & (constant) & 0.468 & 0.124 & & 0.175 & 0.996 \\
\hline & Perceived_Ease & 0.432 & 0.235 & 0.332 & 4.923 & 0.039 \\
\hline & Individual_awareness & 0.085 & 0.235 & 0.119 & 0.707 & 0.037 \\
\hline \multirow{3}{*}{$56-60$} & (constant) & 0.363 & 0.424 & & 2.813 & 0.215 \\
\hline & Perceived_Ease & 0.085 & 0.542 & 0.215 & 0.031 & 0.275 \\
\hline & Individual_awareness & 0.271 & 0.176 & 0.923 & 2.004 & 0.000 \\
\hline \multirow{3}{*}{$61-65$} & (constant) & 1.275 & 0.500 & & 0.042 & 0.143 \\
\hline & Perceived_Ease & 0.654 & 0.502 & 0.225 & 0.542 & 0.032 \\
\hline & Individual_awareness & 0.293 & 0.135 & 0.443 & 0.031 & 0.008 \\
\hline \multirow{3}{*}{$66-70$} & (constant) & 0.045 & 0.081 & & 2.004 & 0.443 \\
\hline & Perceived_Ease & 1.091 & 0.775 & 0.021 & 0.031 & 0.021 \\
\hline & Individual_awareness & 0.864 & 0.124 & 0.483 & 0.549 & 0.567 \\
\hline
\end{tabular}

Source: SPSS Output, Survey data 2020.

\subsection{Moderating Effect of Income}

The adoption of the mobile financial services by the income group less than Tanzanian Shillings (TZS) 50,000 is the same as the income level above TZS 50,000 to 100,000. The moderating effect of income above TZS 100,000 to 200,000 is highly significant on perceived ease of use and on individual awareness. The moderating effect of income above TZS 200,000 to 500,000 is highly significant on perceived ease of use and on individual awareness on the adoption of the mobile financial services. The income group level of the respondents above TZS 500,000 show the moderating effect significant to perceived ease of use, individual awareness on the 
adoption of the mobile financial services.

Therefore, the low income earners enjoy the factors more (perceived ease of use, perceived cost, individual awareness and perceived usefulness) than the high income earners.

Table 10. Effects of level of income on adoption

\section{Model Summary}

\begin{tabular}{llllll}
\hline Income level & R & R2 & Adjusted $\mathbf{R}^{2}$ & Std. Error estimate & Durbin-Wtson \\
\hline Less than TZS 50,000 & $0.347^{\mathrm{a}}$ & 0.444 & 0.608 & 0.500 & 1.900 \\
Above TZS 50,000 to 100,000 & $0.814^{\mathrm{b}}$ & 0.783 & 0.794 & 0.290 & 1.511 \\
Above TZS 100,000 to 200,000 & $0.751^{\mathrm{c}}$ & 0.345 & 0.209 & 0.308 & 1.229 \\
Above TZS 200,000 to 500,000 & $0.505^{\mathrm{b}}$ & 0.309 & 0.266 & 0.992 & 2.090 \\
Above TZS 500,000 & $0.872^{\mathrm{a}}$ & 0.803 & 0.710 & 0.401 & 1.510 \\
\hline
\end{tabular}

Table 11. Anova results income level

\begin{tabular}{|c|c|c|c|c|c|c|}
\hline I Income Level & & Sum of squares & Df & Mean square & $\mathbf{F}$ & Sig. \\
\hline \multirow{3}{*}{ Less than TZS 50,000 } & Regression & 49.901 & 4 & 35.055 & 115.589 & $0.000^{\mathrm{a}}$ \\
\hline & Residual & 1.002 & 99 & 0.209 & & \\
\hline & Total & 142.113 & 103 & & & \\
\hline \multirow{3}{*}{ Above TZS 50,000 to 100,000} & Regression & 39.448 & 4 & 35.679 & 139.090 & $0.000^{\mathrm{b}}$ \\
\hline & Residual & 22.004 & 86 & 0.909 & & \\
\hline & Total & 129.011 & 90 & & & \\
\hline \multirow{3}{*}{ Above TZS 100,000 to 200,000} & Regression & 28.796 & 5 & 25.873 & 25.606 & $0.004^{\mathrm{d}}$ \\
\hline & Residual & 13.200 & 67 & 0.290 & & \\
\hline & Total & 78.071 & 55 & & & \\
\hline \multirow{3}{*}{ Above TZS 200,000 to 500,000} & Regression & 25.430 & 3 & 0.055 & 1.278 & $0.101^{\mathrm{b}}$ \\
\hline & Residual & 9.000 & 64 & 0.035 & & \\
\hline & Total & 35.243 & 70 & & & \\
\hline \multirow{3}{*}{ Above TZS 500,000 } & Regression & 45099 & 4 & 24.220 & 65.024 & $0.056^{\mathrm{d}}$ \\
\hline & Residual & 35.889 & 87 & 0.189 & & \\
\hline & Total & 8.001 & 72 & & & \\
\hline
\end{tabular}

Table 12. Results of the coefficients value for income level

\begin{tabular}{|c|c|c|c|c|c|c|}
\hline Age & & B & Std. Error & Standardized coefficients & $\mathbf{T}$ & Sig. \\
\hline \multirow{3}{*}{ Less than TZS 50,000 } & (constant) & 1.678 & 0.766 & & 0.120 & 0.013 \\
\hline & Perceived_Ease & 0.042 & 0.238 & 0.990 & 0.980 & 0.034 \\
\hline & Individual_awareness & 0.211 & 0.144 & 0.099 & 3.960 & 0.007 \\
\hline \multirow{3}{*}{ Above TZS 50,000 to 100,000} & (constant) & 1.422 & 0.998 & & 0.116 & 0.004 \\
\hline & Perceived_Ease & 0.455 & 0.102 & 0.109 & 2.099 & 0.020 \\
\hline & Individual_awareness & 0.167 & 0.211 & 0.009 & 1.243 & 0.004 \\
\hline \multirow{3}{*}{ Above TZS 100,000 to 200,000} & (constant) & 0.443 & 0.421 & & 3.003 & 0.009 \\
\hline & Perceived_Ease & 0.978 & 0.092 & 0.145 & 0.172 & 0.300 \\
\hline & Individual_awareness & 0.059 & 0.149 & 0.003 & 1.976 & 0.343 \\
\hline \multirow{3}{*}{ Above TZS 200,000 to 500,000} & (constant) & 1.877 & 0.103 & & -1.900 & 0.998 \\
\hline & Perceived_Ease & 0.129 & 0.323 & 0.198 & 0.332 & 0.000 \\
\hline & Individual_awareness & 0.355 & 0.022 & 0.045 & 0.555 & 0.097 \\
\hline \multirow{3}{*}{ Above TZS 500,000 } & (constant) & 0.589 & 0.212 & & -0.321 & 0.678 \\
\hline & Perceived_Ease & 0.009 & 0.222 & 0.322 & 0.864 & 0.244 \\
\hline & Individual_awareness & 0.199 & 0.229 & 0.444 & 0.221 & 0.032 \\
\hline
\end{tabular}

Source: SPSS Output, Survey data 2020.

\subsection{Moderating Effects of Gender on Adoption}

The results on adoption of mobile financial services on the gender of the respondents, the model fits (adjusted $\mathrm{R}^{2}$ ) 
are more than four-fifths and all models were significant (from ANOVA tests). The model results show that both male and female have highly moderating effect on adoption of the mobile financial services. Individual awareness was significant for male, whereas perceived ease of use was not significant for females. Cost effect had negative effects to both females and males. It therefore can be concluded that gender has moderating effects on the adoption of mobile phone financial services.

Table 13. Model summary

\begin{tabular}{llllll}
\hline Gender & R & R2 & Adjusted $^{2}$ & Std. Error estimate & Durbin-Wtson \\
\hline Male & $0.966^{\mathrm{a}}$ & 0.801 & 0.785 & 0.602 & 1.883 \\
Female & $0.945^{\mathrm{b}}$ & 0.818 & 0.823 & 0.631 & 2.222 \\
\hline
\end{tabular}

Table 14. Anova results gender

\begin{tabular}{lllllll}
\hline GeGender & & Sum of squares & Df & Mean square & F & Sig. \\
\hline \multirow{4}{*}{ Male } & Regression & 150.201 & 4 & 37.550 & 113.641 & $0.000^{\mathrm{a}}$ \\
& Residual & 32.712 & 99 & 0.330 & & \\
& Total & 182.913 & 103 & & & \\
\multirow{3}{*}{ Female } & Regression & 146.248 & 4 & 36.562 & 138.000 & $0.000^{\mathrm{b}}$ \\
& Residual & 22.785 & 86 & 0.265 & & \\
& Total & 169.033 & 90 & & & \\
\hline
\end{tabular}

Table 15. Results of the coefficients value for gender

\begin{tabular}{lllllll}
\hline Gender & & B & Std. Error & Standardized coefficients & T & Sig. \\
\hline \multirow{2}{*}{ Male } & (constant) & 0.941 & 0.343 & & 2.005 & 0.006 \\
& Perceived_Ease & 0.042 & 0.189 & 0.032 & 0.339 & 0.734 \\
& Individual_awareness & 0.457 & 0.144 & 0.543 & 4.231 & 0.000 \\
& (constant) & 1.541 & 0.375 & & 4.232 & 0.000 \\
Female & Perceived_Ease & 0.345 & 0.108 & 0.432 & 3.875 & 0.000 \\
& Individual_awareness & 0.127 & 0.221 & 0.143 & 1.198 & 0.234 \\
\hline
\end{tabular}

Source: SPSS Output, Survey data 2020.

\section{Discussion of the Results}

The main purpose of this research was to find out the role of demographics as moderator in individual mobile financial services adoption in rural Tanzania.

The two main factors, namely individual awareness and perceived ease of use were recognized as very important factors to examine adoption of the mobile financial services.

There is a positive and significant relationship between individual awareness and the adoption of the mobile financial services. This flashes the information to the service providers to increase the awareness of these financial services to users and encourage non-users of these services to use them. By so doing, the number of users of the mobile phone financial services will increase especially in the rural areas.

There is also a positive and significant relationship between the perceived ease of use and the adoption of the mobile phone financial services. The simple procedures to follow in order to access financial services through the mobile phone acts as a catalyst to induce people to use these services.

Moreover, there is an effect of gender in moderating the relationship between the individual awareness and perceived ease of use, and the adoption of the mobile financial services. Male gender adopts more financial services than female gender. Also, Male gender is more aware of the mobile phone financial services than female gender.

Also, the effects of the income in moderating the relationship between the individual awareness and perceived ease of use, and the adoption show that, small income earners do not adopt more financial services than high income earners. High income earners are more aware and perceived the ease of use more than less income earners. 


\section{Implication of the Research Findings}

This research study gives insight in order to enhance adoption level of the mobile phone services by considering the effects of demographic variables. The main implication of this research has been encountered in two ways:

The first one is that it helps to understand the adoption behavior of users and non-users of the mobile financial services. Thus, the moderating effects have to be considered in the formulating strategies to encourage mobile phone users to use mobile financial services.

The second is that the demographic variables have to be considered in the theories which explain the behavior of the mobile phone users in accessing mobile financial services. That means, the factors such as level of income, level of education and gender have a lot to offer regarding the mobile phone users to decide, adopt and use mobile financial services. This research adds to the UTAUT based on the demographic variables.

\subsection{Limitations and Future Scope of Study}

The current study was not free from limitations. First, the study has been conducted on users and non-users of mobile phone financial services in the rural Mtwara region only which may not be applicable to other areas, especially urban areas in the country. Also, only three determinant variables on one dependent variable have been included for the study while other variables such as perceived cost and perceived usefulness are also important. Both of these variables could be investigated in future research. Since the examination has been done on the basis of self-structured questionnaire, it can lead to chances of biasness. Moreover, a linear additive model has been used with specified variables. However, there can be a chance that other forms of the model (non-linear or multiplicative) could give different results from current results.

\section{References}

Abdinoor, A., \& Mbamba, U. O. (2017). Factors influencing consumers' adoption of mobile financial services in Tanzania. Cogent Business and Management, 4(1),

Abor, J. Y., Amidu, M., \& Issahaku, H. (2018). Mobile telephony, financial inclusion and inclusive growth. Journal of African Business, 19(3), 430-453.

Adjei, J. K., Odei-Appiah, S., \& Tobbin, P. E. (2019). Explaining the determinants of continual use of mobile financial services. Digital Policy, Regulation and Governance.

Ahmad, S., \& Ghani, A. H. A. (2010, March). The relationship between entrepreneurial orientation and business performance of Malaysia SMEs. In the 2nd International Conference on Arab-Malaysian Islamic Global Business and Entrepreneurship, Kuala Lumpur.

Akhtar, S., Irfan, M., Sarwar, A., \& Rashid, Q. U. A. (2019). Factors influencing individuals' intention to adopt mobile banking in China and Pakistan: The moderating role of cultural values. Journal of Public Affairs, 19(1).

Al-rawahna, A. S. M., Hung, C. W., \& Chen, S. C. (2018). Readiness of government organizations for cloud-computing age: An empirical evidence from Jordan. Journal of Business and Management Sciences, 6(4), 152-162.

Asongu, S., \& Boateng, A. (2018). Introduction to special issue: Mobile technologies and inclusive development in Africa. Journal of African Business, 19(3), 297-301. https://doi.org/10.1080/15228916.2018.1481307

Bentler, P., Bagozzi, R., \& Cudeck, R. (2001). SEM using correlation or covariance matrices. Journal of consumer Psychology, 10(1/2), 85-87.

Bhanot, D., Bapat, V., \& Bera, S. (2012). Studying financial inclusion in North - East India. International Journal of Bank Marketing.

Chawla, D., \& Joshi, H. (2017). Role of demographics as moderator in mobile banking adoption. Cheney, J. S. (2008). An examination of mobile banking and mobile payments: building adoption as experience goods? FRB of Philadelphia-Payment Cards Center Discussion Paper, (08-07).

Chong. (2013). Role of demographics as moderator in mobile banking adoption. Twenty-third Americans Conference on information Systems, Boston.

David-West, O., Iheanachor, N., \& Umukoro, I. O. (2019). Mobile money as a frugal innovation for the bottom of the pyramid-Cases of selected African countries. Africa Journal of Management, 5(3), 274-302.

Economides, N., \& Jeziorski, P. (2017). Mobile money in Tanzania. Marketing Science, 36(6), 815-837.Gurme, 
V. M. (2019). An empirical study on customers' adoption of e-wallet with special reference to Pune city. International Journal of Engineering Applied Sciences and Technology.

Hooper, D., Coughlan, J., \& Mullen, M. (2008). Structural equation modelling: Guidelines for determining model fit. Electronic Journal of Business Research Methods, 6(1), 53-60.

Kim, M., Zoo, H., Lee, H., \& Kang, J. (2018). Mobile financial services, financial inclusion, and development: A systematic review of academic literature. The Electronic Journal of Information Systems in Developing Countries, 84(5), e12044.

Lee, A. et al. (2012). Can the demographic and subject norms influence the adoption of mobile banking? International Journal Mobile Communications, 10(6), 578-597.

Lotto, J. (2018). Examination of the status of financial inclusion and its determinants in Tanzania. Sustainability, $10(8), 2873$.

Lwoga, E. T., \& Lwoga, N. B. (2017). User Acceptance of Mobile Payment: The Effects of User-Centric Security, System Characteristics and Gender. The Electronic Journal of Information Systems in Developing Countries, 81(1), 1-24

Mariscal, J., \& Rojas-Lozano, D. (2020). A State-led Model of Financial Inclusion Through Mobile Services. Information Technologies \& International Development, 16, 12.

Marumbwa, J., \& Mutsikiwa, M. (2013). An analysis of the factors influencing consumers' adoption of mobile money transfer services (MMTs) in Masvingo urban, Zimbabwe. Journal of Economics, Management and Trade, 498-512.

Mashimba, S. H., \& Kühl, R. (2014). Performance of Micro and Small-Scale Enterprises (MSEs) in Tanzania: Growth Hazards of Fruit and Vegetables Processing Vendors. Journal of Applied Economics \& Business Research, 4(2).

Mazer, R., \& Rowan, P. (2016). Competition in mobile financial services: Lessons from Kenya and Tanzania. The African Journal of Information and Communication, (17), 39-5.

Nyambura, M. M. (2013). Determinants of investment in the informal venture capital market in Kenya (Doctoral dissertation), Strathmore University, Kenya.

Odoom, R., \& Kosiba, J. P. (2020). Mobile money usage and continuance intention among micro enterprises in an emerging market-the mediating role of agent credibility. Journal of Systems and Information Technology, 1328-7265.

Osabuohien, E. S., \& Karakara, A. A. (2018). ICT usage, mobile money and financial access of women in Ghana. Africagrowth Agenda, 15(1), 14-18.

Ouma, S.A., Odongo, T. M., \& Were, M. (2017). Mobile financial services and financial inclusion: Is it a boon for savings mobilization? Review of Development Finance, 7(1), 29-35.

Oxford, R. L. (1990). Language learning strategies-What every teacher should know. Heinle \& Heinle.

Oxford, R. L., \& Burry-Stock, J. A. (1995). Assessing the use of language learning strategies worldwide with the ESL/EFL version of the Strategy Inventory for Language Learning (SILL). System, 23(1), 1-23.

Richard, E., \& Mandari, E. (2017). Factors influencing usage of mobile banking services: The case of Ilala district in Tanzania. Orsea Journal 7(1), 42-54.

Shareef, M. A., Baabdullah, A., Dutta, S., Kumar, V., \& Dwivedi, Y. K. (2018). Consumer adoption of mobile banking services: An empirical examination of factors according to adoption stages. Journal of Retailing and Consumer Services, 43, 54-67. http://dx.doi.org/10.1016/j.jretconser.2018.03.003

Simiyu, C. N., \& Oloko, M. (2015). Mobile money transfer and the growth of small and medium sized enterprises in Kenya: A case of Kisumu city, Kenya. International Journal of Economics, Commerce and Management, 3(5), 1056-1065

Srivastava, D. R. (2015). Financial inclusiveness: The role of mobile money and digital financial services. Socrates, 3(1), 95-112. Retrieved from http:// www.socratesjournal.com

Steiger, J. H. (2007). Understanding the limitations of global fit assessment in structural equation modeling. Personality and Individual Differences, 42(5), 893-898.

TCRA. (2020). Market Information of Network Service Providers, Dar es Salaam, Tanzania. 
URT. (2020). Insight that Drive innovation; Financial sector Deepening Trust: Dar-es-salaam, Tanzania.

Venkatesh, V., Morris, M. G., Davis, G. B., \& Davis, F. D. (2003). User acceptance of information technology: Toward a unified view. MIS Quarterly, 425-478.

Wang, X, \& Guan, J. (2017). Financial Inclusion measurement, spatial effects, and influencing factors, Applied Economics, 49(18), 1751-1762

World Bank. (2018). World development report 2018: Learning to realize education's promise. The World Bank.

\section{Copyrights}

Copyright for this article is retained by the author(s), with first publication rights granted to the journal.

This is an open-access article distributed under the terms and conditions of the Creative Commons Attribution license (http://creativecommons.org/licenses/by/4.0/). 